UDC 349.6

DOI https://doi.org/10.37687/2413-7189.2019.3.6

\author{
Kostytsky V., \\ Doctor of Law (DrSc.), Professor, \\ President of the International Environmental Academy \\ ORCID: 0000-0003-1692-9810
}

\title{
FROM THE ECOLOGICAL FUNCTION OF THE STATE TO THE CREATION OF ECOLOGICAL STATE
}

\section{ВІД ЕКОЛОГІЧНОЇ ФУНКЦІї ДЕРЖАВИ ДО СТВОРЕННЯ ЕКОЛОГІЧНОЇ ДЕРЖАВИ}

The article deals with the socio-legal problems of the emergence of the ecological function of the state, its content, as well as features of constitutional consolidation. The author also analyzes the peculiarities of the state's environmental policy, its relationship with the environmental function. The statement of the ecological function of the state as a condition for the implementation of its environmental policy is determined as the basis for the formation of a new model of the state, which the author calls the ecological state. The article presents the features of the ecological state, as well as the problems of realization of ecological binding of the state to the society, the possibility of its realization, provided the liberal content of the organization and the exercise of power are preserved. We have the reason to speak about the possibility of recognition of Ukraine as an ecological state, which is formed within the framework of the mentioned theoretical and methodological paradigm. In particular, the Constitution of Ukraine enshrines the ecological function of the state, approved the economic and legal mechanism of environmental protection, which implemented the international legal principle "polluter pays". Public organizations have acquired access to participate in determining the state's environmental policy. Hence the need to underpin the State's obligations to civil society for the human right to a favorable environment and the principle of the rule of law, which embodies both the recognition of a person of the highest social value and the definition of environmental rights and freedoms, above all, the fundamental human right to favorable environment, which determines the content and orientation of the state.

Key words: liberalism, liberal state, environmental law, ecological function of the state, ecological policy, ecological state.

У статті розглядаються соціолого-правові проблеми виникнення екологічної функції держави, ї̈ зміст, а також характер конституційного закріплення. Автор також аналізує особливості екологічної політики держави, ї̈ взаємозв'язок з екологічною функиією. Утвердження екологічної функції держави як умови реалізації їі екологічної політики визначається як основа формування нової моделі держави, яку автор називає екологічною державою. У статті наводяться ознаки екологічної держави, а також досліджуються проблеми реалізаиії екологічного обв'язку держави перед суспільством, можливості його реалізації за умови збереження ліберального змісту організаиії та здійснення влади. Доводиться думка про те, що сьогодні у нас є підстави говорити про можливість визнання України екологічною держсавою, яка формується в рамках згаданої теоретико-методологічної парадигми. Зокрема, Конституиія України закріплює екологічну функиію держави та затверджує економіко-правовий механізм охорони навколишнього середовища, який реалізовує міжснародно-правовий принцип «забруднювач має платити». Обстоюється твердження, щуо громадські організаиії повинні отримали доступ до участі у визначенні екологічної політики держави. Обтрунтовується висновок про необхідність підкріплювати зобов'язання держави перед громадянським суспільством щодо забезпечення права людини на сприятливе навколишнє природне середовище та принцип верховенства права, який полягає у визнанні людини найвищою соцііальною ичінністю. Встановлено, щзо забезпечення екологічних прав і свобод, насамперед основного права людини на сприятливе довкілля, визначає зміст та спрямованість держави.

Ключові слова: лібералізм, ліберальна держава, екологічне право, екологічна функиія держави, екологічна політика, екологічна держава.

Introduction. Today, the modern state of European-American civilization faces challenges that are almost unrealistic to realize within the traditional framework of a liberal state. It is an issue of environmental protection, ensuring human rights in a favorable environment and avoiding a global ecological disaster, combating poverty, combating terrorism, harmonizing the interests of the state and society, and the interests of the participants in mass transfers to the European Union from the countries of North Africa and the Middle East. For Ukraine, the question of choosing the optimal model of the state is complicated by the problems of the transition period, including external aggression and the loss of control over the part of the sovereign territory, the need for the reform of the administrative and territorial system in order to eliminate the remnants of the administrative-command system, raw material orientation of the economy, prosperity of corruption, imbalance between the branches of power and frequent political crises, incompleteness of the structuring of civil society and party building, and others. As a theoretical and methodological substantiation of what model of the state to replace the 
post-industrial state in the new world order, the advisability of combining the strengthening of state functions and the need to preserve liberal human rights and freedoms against the background of global environmental challenges, creation of an ecological state.

Content. Therefore, the following question emerges: what model of the state should replace the legal state without losing its value gains, such as the rule of law, the distribution of power, the guarantee of human and civil rights and freedoms, to solve environmental problems. The answer to this question is the theoretical and methodological justification of certain changes in the Constitution of Ukraine, which is today the Social Contract between the Ukrainian people on human and civil rights and freedoms and on the model of state power, as well as an agreement between civil society and the state on mutual rights and obligations, on which the state becomes a service of the people, and the understanding of the essence, tasks and functions of the state, including the ecological function of the state, which should combine liberal values with the strengthening of state interference in the sphere of public life associated with the safety of society and human and environmental safety.

Of course, now we are talking about the power of the people and state and self-governmental power. The balance of rights and the balance between civil society sectors and between civil society and the state is optimal for a person and a normal social life. Such an ideal state, in our opinion, is achieved with the advent of an era of a law-governed state, which manifests itself as a kind of only possible compromise between the etatist state of the past, which exaggerated the society and controlled it up to the interference with private and family life, as well as extreme liberalism, accompanied by manifestations of anarchism, the war in the sectors of the economy, the ohlocratic methods of exercising power and even the abuse of law.

We regard the creation of an optimal model of the institution of power as one of the most important constituents of the Constitution of Ukraine - the Social Contract, along with the consolidation of human rights and freedoms and the definition of guarantees for their implementation.

Civil society, as a result of European-American development, is based on pluralism, which is based on the principle of self-determination of the individual, guaranteeing the human and civil rights and freedoms, state-public partnership. The existence of ecological law $[4,2016]$ system and social necessity in the environmental protection require the ecological state function separation.

In legal literature the state functions are the basic directions of its activity directed on solution of the common matters of subjects of society. At the same time realization of some state functions is executed through the activity inside and outside of the country by participating in the international community life. The ecological function requires its separate consideration in the system of functions of state as a political organization of society.

State ecological function came into being not long ago and simultaneously with intensifying of the problem of natural environmental protection. Earlier the question of regulation of nature using and protection was included in the state economic activity and considered as manifestation of its economic function [2]. Worsening of ecological situation, increasing of the role and importance of interaction between society and nature resulted into the necessity of appearance of separate ecological function among other internal state functions.

At the same time there are other grounds of separation of ecological function from the modern state functions in special scientific literature. Sometimes such grounds are predefined by the environmental protection requirements and quality new social and economic situation, i.e. transition of the world vanguard to the stage of post-industrial or information development with the following processes: increase of demand on the corresponding scientific and information resources, displacement of accents in the means of using of natural resources; transition to the economy of preservation of resources; transfer of all social life to the so-called stable development.

State ecological function is realized by the appropriate economic, organizational and legal mechanisms. In addition state legal mechanism is the instrument of implementation of ecological legal function as a new and earlier unknown legal function. It is realized side by side with traditional legal functions, such as: political, economic, cultural and educative, etc. Formation and development of legal ecological function is the result of development and deepening of social contradictions between society and nature, understanding of the need and necessity of considerable extension of legal intervention in the regulation of relations in the sphere of environmental protection and using of natural resources.

The purpose of legal ecological function is ensuring of natural environment quality under the conditions of social economic development by legal regulation instruments. This purpose is attained by drafting, adoption and application of legal norms represented the requirements of ecological regularities concerning interaction of society and nature which consolidate the scientifically proved norms of economic influence on the environment [3].

In our opinion, the analysis of correlation between all state functions is more efficient and depends on their objects. Certainly, the ecological function is not permanent concomitant of state organization of society. Moreover, it is possible to ascertain its late appearance as a separate state function only in the second part of the XX century. Till that time this function was fundamental part of state economic function and it was realized as a constituent part of state economic policy. However, today in some special scientific research we can find the environmental protection interpretation as a component part of state social and economic policy [4].

State ecological function began to separate only for some time past due to the progressing worsening of the natural environment condition of the planet. The modern manufacture development (output of minerals, development of the chemistry, metallurgy, etc.), using of the new- 
est technologies by which human breaks the natural balance that existed during millions of years, appearance of huge amount of wastes including the atomic manufacture wastes do harm the ecosystem and have irreversible consequences. For example, the Chornobyl nuclear disaster in Ukraine was constitutionally recognized as a planetary catastrophe. Therefore, a state more and more actively operates in the sphere of recovery of the broken balance.

Today we can see a raise of the role and importance of this state function on the example of constitutions adopted in the second part of the XX century. As a rule, they consolidated the state policy novels in the sphere of environmental protection and defence. Constitutional consolidation of the state ecological function is the first evidence of importance of this state activity direction under the present-day conditions.

The main positions regarding the essence and direction of the state ecological policy of Ukraine are included in the base legislative act on the questions of environmental protection, i.e. in the Law of Ukraine "On protection of the natural environment" dated June, $25^{\text {th }}$ 1991. This law stipulates that Ukraine realizes the ecological policy on its territory, directed to the prevention of environment which is safe for life of animate and inorganic natures, defence of human life and health from negative influence of the natural environment pollution, achievement of the harmonious interaction between society and nature, protection, sustainable use and recreation of natural resources. So, the ecological policy is one of the state activity directions which has corresponding priorities and tasks of social and economic, natural and social character.

The ecological policy strategy is the course of state ecological policy, aimed at the long-term prospects and solution of the important economic and social tasks, tasks of cultural development, ensuring of state ecological safety, preservation and increase of its natural potential and national wealth, defence of ecological rights and freedoms of physical and legal entities, increase of national well-being.

In general policy is a special activity on the administration of state and society, organizing and supervisory sphere of society which manage the economic, legal, social, cultural, and religious spheres, etc [5]. The term "policy" comes from Greece and means something state-related. This term takes rise from Aristotle's treatise "Policy" about state, administration and government.

Ecological policy is a combination of methods and means of influence of state and other political institutes on the "society and nature" system with a purpose to solve its conflicts timely and ensure the favourable environment of existence of human and society at present and in prospect.

Separate scientists determine the ecological policy as an organizing and regulative and control activity of society and state directed to the environmental protection and improvement, ensuring of the normal vital activity and ecological safety of citizens. But this term reflects rather desirable than real things.
Ecological policy as ecological strategy and ecological tactics is a form of realization of the state ecological function. Ecological policy is the expression of forms and methods of realization of state ecological function in the concrete historical conditions by the concrete political systems. Therefore, analysis of ecological platforms of separate political forces and political parties, especially during pre-election company, is very important for evaluation of the ecological policy efficiency. In Ukraine the political parties continue to establish their own ecological priorities which do not have any real character.

State applies various instruments and mechanisms of regulation of economic activity in the sphere of management of nature or realization of ecological policy, purpose-oriented ecological programs and related with them programs of economic and social development. The main means of state regulative influence on the activity of market participants in the field of environmental protection are the following: ecological taxation; licensing; certification and standardization; application of standards and limits; regulation of prices and tariffs; granting of investment, taxation and other privileges; granting of dotations, compensations, purpose-oriented innovations and subsidies.

Modern phase and peculiarities of realization of the state ecological function are characterized by two opposite processes, such as: on the one hand, it is intensification and deepening of globalization processes; on another hand, there are certain tendencies of solving of national ecological problems on account of other states. But domination of the second tendency contravenes the possibility of averting of global ecocatastrophe and ensuring of the effective cooperation in the sphere of state ecological policy.

At the same time the state role strengthening both inside of the country and in the system of international relations does not means that a burden of transfer to the stable development has to be concentrated on the state without any interaction between state and civil society. In $\mathrm{S}$. Shmidheini opinion, who hold a position of the Head of the Council of entrepreneurs on the questions of stable developmen "it is impossible to realize the stable development conception only by the governmental decisions, because billions of people participate in the manufacture and consumption processes.

While realization of the state ecological function under the conditions of transitional period the role of state administration and regulation will objectively increase.

The state can be called the ecological state if it meets certain criteria, when its functioning is based on certain conditions:

- the Institute for Environmental Rights and Freedoms of Human Rights is materialized in legislation;

- the ecological function of the state and its environmental responsibilities to society and man in accordance with the principle of the rule of law are enshrined in the constitution as a social treaty;

- environmental law system is developed;

- institutional frameworks have been created to ensure the implementation of the state's ecological function; 
- a balanced economic and legal mechanism for environmental protection is formed - there is an independent public control of the society over the implementation of environmental legislation;

- the principle of joint responsibility of the state and society for the future living environment is approved;

- there is a public environmental dialogue;

- the basis of the state environmental policy - the human right to a favorable living environment;

- the ecological and legal culture, which underlies decision-making processes is developed;

- the environmental and legal motivations of the behavior and life of the elite are formed.

It can be noted that today we have the reason to speak about the possibility of recognition of Ukraine as an ecological state, which is formed within the framework of the mentioned theoretical and methodological paradigm. In particular, the Constitution of Ukraine en- shrines the ecological function of the state, approved the economic and legal mechanism of environmental protection, which implemented the international legal principle "polluter pays". Public organizations have acquired access to participate in determining the state's environmental policy. We have developed advanced environmental legislation that enshrines environmental human rights and freedoms. At their core - the right to environmental safety, guaranteed by Art. 50 of the Constitution of Ukraine. The same model occurs in several other states.

Hence the need to underpin the State's obligations to civil society for the human right to a favorable environment and the principle of the rule of law, which embodies both the recognition of a person of the highest social value and the definition of environmental rights and freedoms, above all, the fundamental human right to favorable environment, which determines the content and orientation of the state.

\section{References:}

1. Combating environmental crimes. (Criminal and Criminal Investigation). Kiev : Sciences. opinion, 1994. P. 9.

2. Kostytsky V. Ecological function of the state and economic and legal mechanism of environmental protection. Law of Ukraine. 2004. №1. P. 147.

3. Petrov V.V. The concept of interaction between society and nature - the scientific basis of environmental law / Methodological problems of law / Ed. MN Marchenko. Moscow : Moscow State University Publishing House, 1994. P. 138.

4. Kostytsky V.V Environmental Law of Ukraine: [textbook] 1 book. Drohobych: Circle, 2012. 360 p.

5. Politology. Textbook / Edited by prof. Kremena VG, prof. Gorpacha M.I. Kharkiv : Unicorn Printing Center, 2001.640 p. 